\title{
STUDY OF CHEMICAL DISSOLUTION OF Cu98Be ALLOY IN SOLUTIONS BASED ON $\mathrm{FeCl}_{3}$
}

\author{
Vasylii Larin ${ }^{\mathrm{a}}$, Lilya Egorova ${ }^{\mathrm{b}}$ \\ ${ }^{a}$ Scientific Research Institute of Chemistry, Vasylii Karazin National University of Kharkiv, \\ Maidan Svobody, 4, Kharkiv 61077, Ukraine \\ ${ }^{b}$ National Automobile and Highway Universit of Kharkiv, Yaroslava Mudrogo, 25, Kharkiv \\ 61002, Ukraine \\ contactinge-mail lilyaegorova@ukr.net
}

Keywords: beryllium bronze, etching, solution, selectivity of dissolution, complex particles.

Abstract. Process of chemical dissolution of beryllium bronze in various electrolytes was studied. Taking into account complex formation processes during chemical etching in solutions based on $\mathrm{FeCl}_{3}$ the ionization rate and selectivity of dissolution of Cu98Be alloy components was determined. It was shown that uniform and high rated chemical dissolution of beryllium bronze is possible in acidic medium in presence of $\mathrm{Fe}^{3+}$ ion-oxidizer and chlorine ions. An optimal etching solution composition was proposed. The surface morphology of the beryllium bronze electrode after etching in the investigated solutions was studied. An absence of passivation on the alloy Cu98Be surface was shown and salt and oxide nature of the grains of compounds formed on the electrode surface after chemical etching was proved.

\section{Introduction}

Electronics is quite fast developing area of science and technic, one generation replaces another every three-five years. Printed circuit boards are the most important medium of intercompounds in electronics and basic characteristics of electronic devices depend on their quality [1]. Copper foil and its alloys are widely used at assembly factories. Demand of flexible circuit boards of high durability makes up manufacturers of the copper foil to develop new decisions, for example, to use copperberyllium alloys.

Beryllium bronze is used at manufacturing of the circuit boards and is indispensable when good electrical conductivity, mechanical durability and springiness properties are needed at the same time. Due to unique composition of properties, this alloy is one among standards in production of the electrical connectors and spring details of the conversion sensors. It's very important to preserve in these technologies minimal damage 
of the beryllium bronze surface, therefore chemical etching process is used for its preparation. Lately the stamping technology has been used for the spring production. This technology did not supply the required accuracy of production and broke the quality of internal layer and that worsens the efficiency of operation of the device. The maximal permissible deviations from the geometric parameters of the parts are $\pm 10 \mathrm{mkm}$, and losses of the bronze layer due to chemical treatment is not higher than $0,2 \mathrm{mkm}$. [2]. Moreover, toxic dust discharges must be controlled during mechanical treatment but this problem is successfully solved at size treatment of the copper-beryllium alloy by chemical etching operation $[3,4]$.

Difficulties that we meet during anodic treatment of the surface of copper alloys require the detailed study of processes of chemical dissolution of copper alloys, as well as beryllium bronzes in electrolyte solutions of various compositions. The data of investigation has theoretical as well as practical value in production of precise mechanic goods, optics, radio electronics, another adjacent areas, where creation of thin and superthin surface structures, technology of precession etching, making sketches, composition of layers, etc. are needed.

Solid two-component metallic solutions can participate in reactions of anodic oxidation in such a way that ionization is concerned either both components or selectively one of them. As was shown in work [5] practical mechanism of dissolution of homogenous alloys - uniform, pseudoselective and selective, is determined by the probability of formation of new phase grains on the alloy surface and kinetic parameters of the ionization reaction of and reverse sedimentation of ions of the less active component. The most important role in phase formation plays conjugation of the partial reactions of components ionization by suppressing it one can influence the ability of the alloys to the selective dissolution. At study of chemical etching of two component alloys perfect interest possess question of selectivity of dissolution of components from practical point of view. Selective dissolution of alloys is an effective way to obtain nanoporous materials [6]. Selective dissolution can be done not only by lining but also by addition to the solution the complexing agents and surfactants. Consequently, quite important is investigation of process of chemical dissolution of copper alloys in solutions with various composition, considering complex formation process that allows to optimize technological alloys etching process in solutions of various compositions due to choosing the optimal composition of etching solution.

\section{Experimental part}

Material and methods Chemical etching of $\mathrm{Cu} 98 \mathrm{Be}$ was studied by experimental methods of investigations: gravimetry, electronic probe microanalysis, atomic- 
absorption spectrometry. Determination of etching rate by gravimetry was based on rotating disk electrode, made from $\mathrm{Cu} 98 \mathrm{Be}$ bronze. Elementary composition of $\mathrm{Cu} 98 \mathrm{Be}$ alloy was determined by gravimetry according to DOST 15027.13-77. Mass percent of beryllium in $\mathrm{Cu} 98 \mathrm{Be}$ alloy is $1,78 \%$. Morphological peculiarities of the etched surface of $\mathrm{Cu} 98 \mathrm{Be}$ alloy was investigated by electronic probe microanalysis (EPM) method by means of scanning microscope JSM-6390 LV with the system of X-ray microanalysis INCA. The quantity of $\mathrm{Be}^{2+}$ and $\mathrm{Cu}^{2+}$ ions was determined by atomic-absorption spectrometry method using atomic-absorption spectrometer MGA-915 MD. The relative error of measurement in work - 3,5\%

To figure out the material condition (Cu98Be alloy) if it is tempered or old, determination of hardness of the Cu98Be alloy according to Brinelle $H B$ was done by means of the hardness tester UIT-HBW-1S and using program "Determination of hardness of materials by pushing of spherical indenter".

The determined according to Brinelle hardness is $H B=284,3$ which corresponds to an aged state of beryllium bronze [7-8].

It was very important to determine condition of the Cu98Be alloy, because during the aging the processes of decay of fixed by hardening of supersaturated state of alloy take place that leads to the increase of durability of beryllium bronze [9]

\section{Results and discussion}

The main purpose is to investigate processes of chemical ionization, selectivity of dissolution of $\mathrm{Cu} 98 \mathrm{Be}$ alloy, considering complex formation process in solutions, based on $\mathrm{FeCl}_{3}$ and morphology of its surface after etching.

The dissolution rate of the $\mathrm{Cu} 98 \mathrm{Be}$ alloy electrode in various electrolytes was studied by rotating disc electrode method at the rotation rate $74 \mathrm{rps}$. It allows to imitate the hydrodynamic conditions of jet etching and cancel the diffusion limitations on transportation of dissolution products of the copper component to the bulk of solution. On the base of our first investigations of determination of the ionization rate of Cu98Be alloy in various electrolytes, the solution of $\mathrm{FeCl}_{3}$ was chosen as a basic component of etching solution. Dissolution of $\mathrm{Cu} 98 \mathrm{Be}$ alloy in $\mathrm{FeCl}_{3}$ solutions is higher than in other investigated etching solutions. That is due to high oxidizing ability of $\mathrm{Fe}^{3+}$. The high rate of dissolution of beryllium bronze can be reached not only by increase of oxidizing $\mathrm{Fe}^{3+}$ ion concentration, but also by addition of various supplements, which form stable complexes with alloy components. As supplements to the basic electrolyte $\mathrm{KNO}_{3}$, $\mathrm{Fe}\left(\mathrm{NO}_{3}\right)_{3}$ were chosen. The selection of the composition of etching solutions was made on the base of analysis of literature data concerning complex formation of beryllium and copper [1013]. As a third substance $\mathrm{HCl}, \mathrm{H}_{2} \mathrm{SO}_{4}, \mathrm{HNO}_{3}$, 
acids that decrease $\mathrm{pH}$ of solution and increase solubility of beryllium were added. On the base of analysis of values of dissolution rate of the $\mathrm{Cu} 98 \mathrm{Be}$ alloy (table 1)

Table 1. Results of investigation of rate and selectivity of dissolution of beryllium bronze in the solutions, based on $\mathrm{FeCl}_{3}$ (time of etching-20 $\mathrm{min}, \omega=74 \mathrm{rps}^{-1}$ )

\begin{tabular}{|c|c|c|c|c|c|c|}
\hline \multirow[t]{2}{*}{ № } & \multirow[t]{2}{*}{$\begin{array}{l}\text { Composition } \\
\text { of solution, } \\
\mathrm{mol} / 1\end{array}$} & \multirow[t]{2}{*}{$\begin{array}{l}V \cdot 10^{-3}, \\
\mathrm{~kg} / \mathrm{m}^{2} \cdot \mathrm{s}\end{array}$} & \multicolumn{2}{|c|}{$\begin{array}{c}\text { Ions contain, } \\
\mathrm{g} / \mathrm{l}\end{array}$} & \multicolumn{2}{|c|}{$\begin{array}{l}\text { Coefficients of } \\
\text { selectivity of } \\
\text { the alloys } \\
\text { components }\end{array}$} \\
\hline & & & $\mathrm{Be}^{2+}$ & $\mathrm{Cu}^{2+}$ & $Z_{\mathrm{Be}}$ & $Z_{\mathrm{Cu}}$ \\
\hline 1 & $0,5 \mathrm{M} \mathrm{FeCl}_{3}$ & 1,61 & 0,10 & 5,04 & 0,95 & 1,12 \\
\hline 2 & $0,75 \mathrm{M} \mathrm{FeCl}_{3}$ & 2,10 & 0,05 & 3,71 & 0,71 & 1,39 \\
\hline 3 & $1,0 \mathrm{M} \mathrm{FeCl}_{3}$ & 2,60 & 0,09 & 5,57 & 0,81 & 1,24 \\
\hline 4 & $\begin{array}{l}0,5 \mathrm{M} \mathrm{FeCl}_{3}- \\
1,5 \mathrm{M} \mathrm{KNO}_{3}\end{array}$ & 1,67 & 0,05 & 4,70 & 0,50 & 2,04 \\
\hline 5 & $\begin{array}{l}0,5 \mathrm{M} \mathrm{FeCl}_{3}- \\
1,5 \mathrm{M} \mathrm{KNO}_{3}- \\
0,5 \mathrm{M} \mathrm{HCl}^{-}\end{array}$ & 1,97 & 0,04 & 3,53 & 0,60 & 1,72 \\
\hline 6 & $\begin{array}{l}0,5 \mathrm{M} \mathrm{FeCl}{ }_{3}- \\
0,5 \mathrm{M} \mathrm{Fe}\left(\mathrm{NO}_{3}\right)_{3}\end{array}$ & 2,17 & 0,06 & 3,86 & 0,81 & 1,25 \\
\hline 7 & $\begin{array}{l}0,5 \mathrm{M} \mathrm{FeCl}_{3}- \\
0,5 \mathrm{M} \mathrm{Fe}\left(\mathrm{NO}_{3}\right)_{3} \\
-0,25 \mathrm{M} \mathrm{H}_{2} \mathrm{SO}_{4}\end{array}$ & 1,84 & 0,05 & 2,27 & 1,01 & 1,02 \\
\hline 8 & $\begin{array}{l}0,5 \mathrm{M} \mathrm{FeCl}_{3}- \\
0,5 \mathrm{M} \mathrm{Fe}\left(\mathrm{NO}_{3}\right)_{3} \\
-0,5 \mathrm{M} \mathrm{HCl}\end{array}$ & 2,40 & 0,06 & 3,45 & 0,92 & 1,10 \\
\hline 9 & $\begin{array}{l}0,5 \mathrm{M} \mathrm{FeCl}_{3}- \\
0,5 \mathrm{M} \mathrm{Fe}\left(\mathrm{NO}_{3}\right)_{3} \\
-0,5 \mathrm{M} \mathrm{HNO}_{3}\end{array}$ & 2,26 & 0,07 & 4,27 & 0,83 & 1,25 \\
\hline
\end{tabular}

a number of etching solutions with high rate of the alloy ionization with investigated selectivity of dissolution of the components of beryllium bronze were chosen.

Quantitative indicators that show us uniformity or selectivity of alloys dissolutions are coefficient of selectivity of dissolution $\mathrm{Z}$. The coefficients $Z_{\mathrm{Be}}$ и $Z_{\mathrm{Cu}}$ for beryllium bronze were calculated on the base of atomicabsorption analysis for solutions of copper and beryllium ions concentrations that return into solution and by data of precise composition of Cu98Be alloy.
For example, $\mathrm{Z}_{\mathrm{Be}}$ by the formula was calculated:

$$
Z_{\mathrm{Be}}=\frac{\left(\mathrm{Be}^{2+} / \mathrm{Cu}^{2+}\right)_{\text {solution }}}{(\mathrm{Be} / \mathrm{Cu})_{\text {alloy }}}
$$

where $\left(\mathrm{Be}^{2+} / \mathrm{Cu}^{2+}\right)$ solution - ions concentration relation in solution;

where $(\mathrm{Be} / \mathrm{Cu})_{\text {alloy }}$ - components relation in alloy.

Rate of dissolution of $\mathrm{Cu} 98 \mathrm{Be}$ in solution of composition $0,5 \mathrm{M} \mathrm{FeCl}_{3}-1,5 \mathrm{M}$ $\mathrm{KNO}_{3}-0,5 \mathrm{M} \mathrm{HCl}$ is higher than one in solutions $0,5 \mathrm{M} \mathrm{FeCl}_{3}$ and $0,5 \mathrm{M} \mathrm{FeCl}_{3}-0,5 \mathrm{M}$ $\mathrm{Fe}\left(\mathrm{NO}_{3}\right)_{3}-0,25 \mathrm{M} \mathrm{H}_{2} \mathrm{SO}_{4}$. It can be explained that dissolution of the copper component can be supplied by interaction with ions of $\mathrm{Fe}^{3+}$ oxidizer and $\mathrm{Cu}(\mathrm{I})$ chloride complexes formation, but with drain of the etching solution, its concentration decreased and dissolution slowed down [10]. Thus, chloride supplement is necessary to supply dissolution of the copper component, and $\mathrm{HCl}$ was used like it. The highest rate of etching of $\mathrm{Cu} 98 \mathrm{Be}$ is in hydrochloric acid solution. The most important factor for beryllium that caused solubility is the acidity of solutions which is supplied by supplement of $\mathrm{HCl}$ as well.

Selective solubility of copper component of $\mathrm{Cu} 98 \mathrm{Be}$ alloy takes place in solutions of compositions: $0,5 \mathrm{M} \mathrm{FeCl}_{3}-1,5 \mathrm{M} \mathrm{KNO}_{3}-0,5$ $\mathrm{M} \mathrm{HCl} ; 0,5 \mathrm{M} \mathrm{FeCl}_{3}-1,5 \mathrm{M} \mathrm{KNO}_{3}$.

The rate of etching depends on concentration of copper ion in solution. At very low and very high content of copper ions in the 
solution an abrupt change of etching rate occurred. We can see from the histogram in Figure.1 that dependencies of the dissolution rate of $\mathrm{Cu} 98 \mathrm{Be}$ alloy from content of $\mathrm{Cu}^{2+}(\mathrm{g} / \mathrm{l})$, in solution after etching, minimal, and maximal values of ionization rate for beryllium bronze at big contain of copper ions (II) are in solutions № 2 and 8,9 .

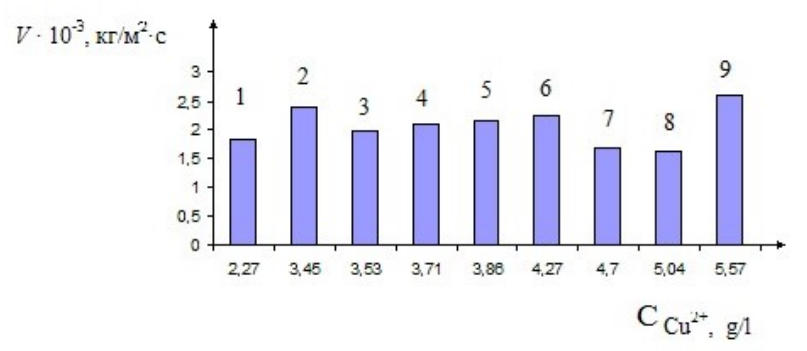

Figure 1. Histogram of dependence of the dissolution rate ( $\tau=20$ min.) of $\mathrm{Cu} 98 \mathrm{Be}$ alloy from copper ions concentration in the solution of composition: $1-(0,5 \mathrm{M}$ $\left.\mathrm{FeCl}_{3}-0,5 \mathrm{M} \mathrm{Fe}\left(\mathrm{NO}_{3}\right)_{3}-0,25 \mathrm{M} \mathrm{H} \mathrm{H}_{2} \mathrm{SO}_{4}\right) ; 2-(0,5 \mathrm{M}$ $\left.\mathrm{FeCl}_{3}-0,5 \mathrm{M} \mathrm{Fe}\left(\mathrm{NO}_{3}\right)_{3}-0,5 \mathrm{M} \mathrm{HCl}\right) ; 3-\left(0,5 \mathrm{M} \mathrm{FeCl}_{3}-\right.$ $\left.1,5 \mathrm{M} \mathrm{KNO}_{3}-0,5 \mathrm{M} \mathrm{HCl}\right) ; 4-\left(0,75 \mathrm{M} \mathrm{FeCl}_{3}\right) ; 5-(0,5 \mathrm{M}$ $\left.\mathrm{FeCl}_{3}-0,5 \mathrm{M} \mathrm{Fe}\left(\mathrm{NO}_{3}\right)_{3}\right) ; 6-\left(0,5 \mathrm{M} \mathrm{FeCl}{ }_{3}-0,5 \mathrm{M}\right.$ $\left.\mathrm{Fe}\left(\mathrm{NO}_{3}\right)_{3}-0,5 \mathrm{M} \mathrm{HNO}\right)_{3} ; 7-\left(0,5 \mathrm{M} \mathrm{FeCl}{ }_{3}-1,5 \mathrm{M}\right.$ $\left.\mathrm{KNO}_{3}\right) ; 8$ - (0,5 $\left.\mathrm{M} \mathrm{FeCl}_{3}\right) ; 9$ - (1,0 $\left.\mathrm{M} \mathrm{FeCl}_{3}\right)$

We can separate two factors that increase the rate of dissolution of $\mathrm{Cu} 98 \mathrm{Be}$ alloy: increase of $\left(\mathrm{Cl}^{-}\right)$ligands concentration to form complexes of copper ions and increase concentration of oxidizing ions $\left(\mathrm{Fe}^{3+}\right)$. In order to dissolve other component of the alloy namely $\mathrm{Be}$, the acidity of the medium should be decreased. On the basis of the above mentioned fact, the following investigations were carried out in the solutions based on $0,5 \mathrm{M} \mathrm{FeCl}_{3}$ (this composition is a single component, but supplied an equable etching with quite high rate (table 1) with addition of $\mathrm{HCl}$ of various concentration (table 2).

As we can see from the results of determination of the rate of proses of etching of beryllium bronze, its value is not sufficiently different for all recommended solutions, and the coefficients of selectivity of dissolution of alloy components are the closest in solution of composition $0,5 \mathrm{M} \mathrm{FeCl}_{3}$ which proves the uniformity of etching. So, this composition of solution supplied not only the high rate but also uniform process of etching of beryllium bronze.

Table 2. The results of investigation of the ionization rate of $\mathrm{Cu} 98 \mathrm{Be}$ alloy and selectivity of dissolution of the alloy components in solutions based on $0,5 \mathrm{M} \mathrm{FeCl}_{3}$.

\begin{tabular}{|c|c|c|c|c|c|c|}
\hline \multirow[t]{2}{*}{ № } & \multirow[t]{2}{*}{$\begin{array}{c}\text { Composition } \\
\text { of solution, } \\
\text { mol/l }\end{array}$} & \multirow[t]{2}{*}{$\begin{array}{c}V \cdot 10^{-} \\
{ }_{3}, \\
\mathrm{Kg} / \mathrm{m}^{2} \cdot \mathrm{s}\end{array}$} & \multirow[t]{2}{*}{$\begin{array}{c}\text { Concen } \\
\text { tration } \\
\mathrm{Cu}^{2+}, \\
\mathrm{g} / 1\end{array}$} & \multirow[t]{2}{*}{$\begin{array}{c}\text { Concen } \\
\text { tration } \\
\mathrm{Be}^{2+}, \\
\mathrm{g} / 1\end{array}$} & \multicolumn{2}{|c|}{$\begin{array}{l}\text { Coefficients of } \\
\text { selectivity of } \\
\text { Cu98Be alloy } \\
\text { components. }\end{array}$} \\
\hline & & & & & $Z_{\mathrm{Cu}}^{2+}$ & $Z_{\mathrm{Be}^{2+}}$ \\
\hline 1 & $0,5 \mathrm{M} \mathrm{FeCl}_{3}$ & 1,61 & 5,04 & 0,10 & 1,12 & 0,95 \\
\hline 2 & $\begin{array}{l}0,5 \mathrm{M} \mathrm{FeCl}_{3} \\
-0,1 \mathrm{M} \mathrm{HCl}\end{array}$ & 1,52 & 1,95 & 0,04 & 1,26 & 0,81 \\
\hline 3 & $\begin{array}{l}0,5 \mathrm{M} \mathrm{FeCl}_{3} \\
-0,25 \mathrm{M} \\
\mathrm{HCl}\end{array}$ & 1,63 & 2,16 & 0,04 & 1,14 & 0,91 \\
\hline 4 & $\begin{array}{l}0,5 \mathrm{M} \mathrm{FeCl}_{3} \\
-0,5 \mathrm{M} \mathrm{HCl} \\
\end{array}$ & 1,75 & 2,31 & 0,04 & 1,17 & 0,87 \\
\hline 5 & $\begin{array}{l}0,5 \mathrm{M} \mathrm{FeCl}_{3} \\
-0,75 \mathrm{M} \\
\mathrm{HCl}\end{array}$ & 1,72 & 2,2 & 0,04 & 1,14 & 0,91 \\
\hline
\end{tabular}

To study an influence of inter ionic interactions in solution on ionization process of $\mathrm{Cu} 98 \mathrm{Be}$ alloy, complex formation in the investigated solutions by distribution of complex particles by projection method was investigated. Complex particle concentrations were calculated with an accuracy up to $10^{-24}$ by program [14]. Values of the stability constants 
for the complexes at ionic strength $\mathrm{I}=1,0 \mathrm{M}$ were taken from [15].

Chemical dissolution of the beryllium bronze was done in acidic solutions of electrolytes. It is well known that if ligands in complex are strong acid anions (for example, $\mathrm{Cl}^{-}, \mathrm{Br}^{-}, \mathrm{I}^{-}, \mathrm{NCS}^{-}$etc), stability of these complexes doesn't depend on the acidity of medium. Formation of complex particles in solution of $0,5 \mathrm{M} \mathrm{FeCl}_{3}$ in various acidity was investigated (table 3 )

Table 3. Acidity of etching solutions of alloys $\mathrm{Cu} 98 \mathrm{Be}$

\begin{tabular}{|c|c|c|}
\hline № & Composition of solution, mol /1 & pH \\
\hline 1 & $0,5 \mathrm{M} \mathrm{FeCl}_{3}-0,75 \mathrm{M} \mathrm{HCl}$ & 0,13 \\
\hline 2 & $0,5 \mathrm{M} \mathrm{FeCl}_{3}-0,5 \mathrm{M} \mathrm{HCl}$ & 0,31 \\
\hline 3 & $0,5 \mathrm{M} \mathrm{FeCl}_{3}-0,25 \mathrm{M} \mathrm{HCl}$ & 0,62 \\
\hline 4 & $0,5 \mathrm{M} \mathrm{FeCl}_{3}-0,1 \mathrm{M} \mathrm{HCl}$ & 1,57 \\
\hline 5 & $0,5 \mathrm{M} \mathrm{FeCl}_{3}$ & 2,06 \\
\hline
\end{tabular}

Insufficient growth of the dissolution rate of $\mathrm{Cu} 98 \mathrm{Be}$ alloy (table 2) can be explained by formation in solutions of iron (III) complexes, that activate dissolution of copper component of the alloy. As we can see from Figure. 2, complex formation in the investigated solution is insignificant.

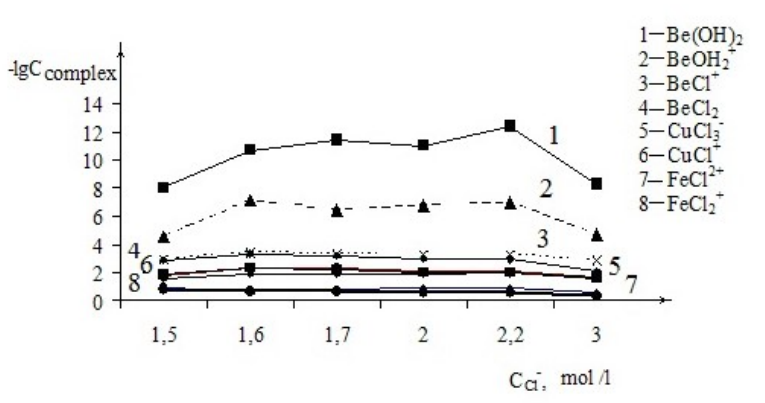

Figure 2. Fig. 2 - Diagram of distribution of complex particles in the system $0,5 \mathrm{M} \mathrm{FeCl}_{3}-\mathrm{n} \mathrm{HCl:} 1-\mathrm{Be}(\mathrm{OH})_{2}$; $2-\mathrm{BeOH}_{2}^{+} ; 3-\mathrm{BeCl}^{+} ; 4-\mathrm{BeCl}_{2} ; 5-\mathrm{CuCl}_{3}^{-} ; 6-\mathrm{CuCl}^{+} ;$ $7-\mathrm{FeCl}^{2+} ; 8-\mathrm{FeCl}_{2}^{+}$
There are no extremes on the diagram of distribution of complex particles, therefore we can not make conclusions about activating influence of a complex particle on ionization process of $\mathrm{Cu} 98 \mathrm{Be}$ alloy in the investigated solutions. The most stable complexes in solutions of iron chloride (III) are $\mathrm{FeCl}_{2}{ }^{+}$, the less stable ones are $\mathrm{FeCl}^{2+}$ and the least stability possess $\mathrm{FeCl}_{3}$ and $\mathrm{FeCl}_{4}^{-}$, respectively.

One can neglect by the influence of copper chloride and beryllium chloride complexes on the dissolution rate of beryllium bronze because the initial etching process was investigated for 20 minutes when the copper ions are accumulated in the solution in small amount. It was shown in works $[16,17]$ that various chloride complexes of iron (III) make various influence on copper ionization. The activity raw of complex particles of $\mathrm{Fe}(\mathrm{III})$ was proposed and according to it acceleration of dissolution of copper takes place in presence of $\left[\mathrm{Fe}\left(\mathrm{H}_{2} \mathrm{O}\right)_{5} \mathrm{Cl}\right]^{2+}$ and $\left[\mathrm{Fe}\left(\mathrm{H}_{2} \mathrm{O}\right)_{4} \mathrm{Cl}_{2}\right]^{+}$complexes. One of the cause of it is increase of the rate constant of electron exchange in the system $\mathrm{Fe}(\mathrm{II}) / \mathrm{Fe}$ (III) at formation of these complexes. Thus at complex formation of iron (III) ions with $\mathrm{Cl}^{-}$-ions the rate increase at the stage of electron transfer from $\mathrm{Cu}(\mathrm{I})$ to the oxidizer - complex $\left[\mathrm{Fe}\left(\mathrm{H}_{2} \mathrm{O}\right)_{5} \mathrm{Cl}\right]^{2+}$ or $\left[\mathrm{Fe}\left(\mathrm{H}_{2} \mathrm{O}\right)_{4} \mathrm{Cl}_{2}\right]^{+}$. Authors of works [18-19] showed that increase of the rate dissolution of copper is coupled to the stable rise of concentration of $\left[\mathrm{Fe}\left(\mathrm{H}_{2} \mathrm{O}\right)_{4} \mathrm{Cl}_{2}\right]^{+}$on the background of slow decrease of concentration of 
$\left[\mathrm{Fe}\left(\mathrm{H}_{2} \mathrm{O}\right)_{5} \mathrm{Cl}\right]^{2+}$ as the total concentration of chloride ions increases.

One can point out from diagrams in Figure. 2 that general tendencies of the complex particles concentration change in solution with the total concentration of chloride ions $\left(\mathrm{C}_{\mathrm{Cl}^{-}}\right)$ increase. Free chloride ions can form complexes with copper and beryllium ions that are transferred to the solution which is important from the point of view of supplement of uniform dissolution of the alloy and sufficient volume of liquid phase of both dissolved components. Concentration of $\left[\mathrm{Fe}\left(\mathrm{H}_{2} \mathrm{O}\right)_{4} \mathrm{Cl}_{2}\right]^{+}$complexes is higher than concentration of the other complex particles of iron (III). As shown in Figure. 2, an insignificant increase in the concentration of all the complex particles of the studied system is observed in the concentration range of the $\mathrm{Cl}$-ion of 2.2-3 mol/1 which corresponds to the composition of etching solution 1 and 2 (Table 3 ) and they have the lowest $\mathrm{pH}$ values. This fact proves that the acidity of the medium promotes the formation of all beryllium complex particles, even $\mathrm{Be}(\mathrm{OH})_{2}$ and $\mathrm{BeOH}_{2}{ }^{+}$, whose concentrations are much lower than the concentrations of chloride complexes of beryllium.

On the base of the obtained results the histograms of dependencies of the fraction distribution of complex particles on the acidity of etching solutions were plotted. As seen from the histogram (Figure. 3), the maximal formation of complex particles of both alloy components is observed in the solution of composition 0,5 $\mathrm{M} \mathrm{FeCl}_{3}$ with quite high fraction of formation of $\mathrm{FeCl}^{2+}$ and $\mathrm{FeCl}_{2}{ }^{+}$ which explains uniform and high rated etching of the alloy Cu98Be in the solution of this composition and is visually presented in Fig.3, solution composition №5 (table №3):

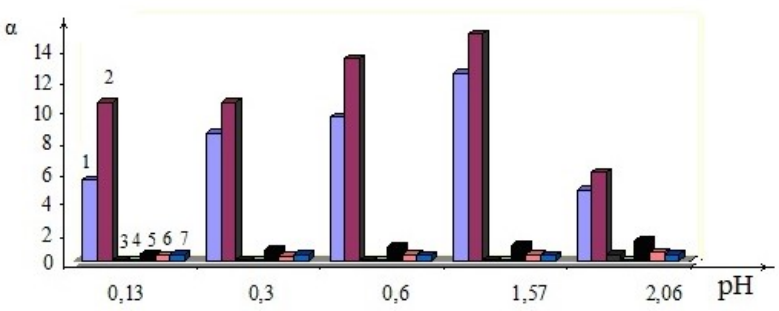

Figure 3. Histogram of fraction distribution of the complex particles depending on $\mathrm{pH}$ of etching solution: 1 $-\mathrm{FeCl}^{2+} ; 2-\mathrm{FeCl}_{2}{ }^{+} ; 3-\mathrm{BeCl}^{+} ; 4-\mathrm{BeCl}_{2} ; 5-\mathrm{CuCl}^{+}$; $6-\mathrm{CuCl}_{2} ; 7-\mathrm{CuCl}_{3}{ }^{-}$

So, 0,5 $\mathrm{M} \mathrm{FeCl}_{3}$ etching solution supplies the high rated, uniform etching, caused by complex formation of copper as well as beryllium.

The morphology of the electrode surface (Figure.4, 5 and table 4) of $\mathrm{Cu} 98 \mathrm{Be}$ after etching in the solutions with maximal value of etching rate and uniformity of dissolution by alloy components (compositions of solutions 1, $7,8,9$ ) (table 1) was studied.

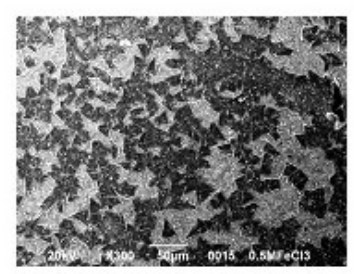

a

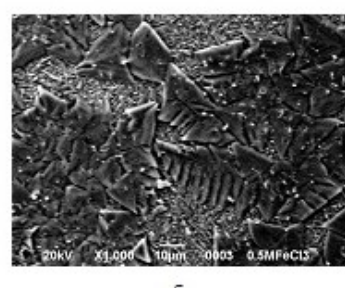

6
Figure 4. Microphotos of the surface of bronze $\mathrm{Cu} 98 \mathrm{Be}$ after etching in $0,5 \mathrm{M} \mathrm{FeCl} 3$ solution at $\omega=74$ rps. Enlargement: $\mathrm{a}-300$ times; $\sigma-1000$ times 
Table 4. The results of investigation of morphology of the electrode surface of Cu98Be after etching by electronic probe microanalysis

\begin{tabular}{|c|c|c|c|c|}
\hline \multirow[t]{2}{*}{ № } & \multirow[t]{2}{*}{$\begin{array}{l}\text { Composition of solution, } \\
\mathrm{mol} / \mathrm{l}\end{array}$} & \multicolumn{3}{|c|}{$\begin{array}{l}\text { The results of electronic probe } \\
\text { microanalysis }\end{array}$} \\
\hline & & $\begin{array}{c}\text { Elemen } \\
\text { ts }\end{array}$ & $\begin{array}{l}\text { Atomic } \\
\text { fraction, } \%\end{array}$ & $\begin{array}{l}\text { Weight } \\
\text { fraction, } \%\end{array}$ \\
\hline \multirow[t]{8}{*}{1} & \multirow{8}{*}{$\begin{array}{l}0,5 \mathrm{M} \mathrm{FeCl}_{3}-0,5 \mathrm{M} \\
\mathrm{Fe}\left(\mathrm{NO}_{3}\right)_{3}-0,25 \mathrm{M} \mathrm{H}_{2} \mathrm{SO}_{4}\end{array}$} & $\mathrm{O}$ & 11,17 & 3,57 \\
\hline & & $\mathrm{Al}$ & 0,16 & 0,08 \\
\hline & & $\mathrm{Si}$ & 0,06 & 0,04 \\
\hline & & $\mathrm{S}$ & 0,10 & 0,07 \\
\hline & & $\mathrm{Cl}$ & 28,56 & 20,23 \\
\hline & & $\mathrm{Fe}$ & 0,06 & 0,07 \\
\hline & & $\mathrm{Ni}$ & 0,55 & 0,64 \\
\hline & & $\mathrm{Cu}$ & 59,33 & 75,30 \\
\hline \multirow[t]{7}{*}{2} & \multirow{7}{*}{$\begin{array}{l}0,5 \mathrm{M} \mathrm{FeCl}_{3}-0,5 \mathrm{M} \\
\mathrm{Fe}\left(\mathrm{NO}_{3}\right)_{3}-0,5 \mathrm{M} \mathrm{HCl}\end{array}$} & $\mathrm{O}$ & 9,75 & 3,15 \\
\hline & & $\overline{\mathrm{Al}}$ & 0,09 & 0,05 \\
\hline & & $\mathrm{Si}$ & 0,20 & 0,11 \\
\hline & & $\mathrm{S}$ & 0,31 & 0,20 \\
\hline & & $\mathrm{Cl}$ & 32,75 & 23,47 \\
\hline & & $\mathrm{Ni}$ & 0,54 & 0,64 \\
\hline & & $\mathrm{Cu}$ & 56,36 & 72,38 \\
\hline \multirow[t]{8}{*}{3} & \multirow{8}{*}{$\begin{array}{l}0,5 \mathrm{M} \mathrm{FeCl}_{3}-0,5 \mathrm{M} \\
\mathrm{Fe}\left(\mathrm{NO}_{3}\right)_{3}-0,5 \mathrm{M} \mathrm{HNO}_{3}\end{array}$} & $\mathrm{O}$ & 3,27 & 0,92 \\
\hline & & $\mathrm{Al}$ & 0,15 & 0,07 \\
\hline & & $\mathrm{Si}$ & 0,11 & 0,05 \\
\hline & & $S$ & 0,23 & 0,13 \\
\hline & & $\mathrm{Cl}$ & 16,44 & 10,20 \\
\hline & & $\mathrm{Fe}$ & 0,09 & 0,09 \\
\hline & & $\mathrm{Ni}$ & 0,78 & 0,80 \\
\hline & & $\mathrm{Cu}$ & 78,93 & 87,75 \\
\hline
\end{tabular}

Dense layers of passivized compounds are absent in microphoto of the etched surface. By focusing the electron beam at the white inclusions, which are seen in microphotoes, salty (chlorides) and oxide nature of these compounds was established (Figures. 4, 5 and table 4).
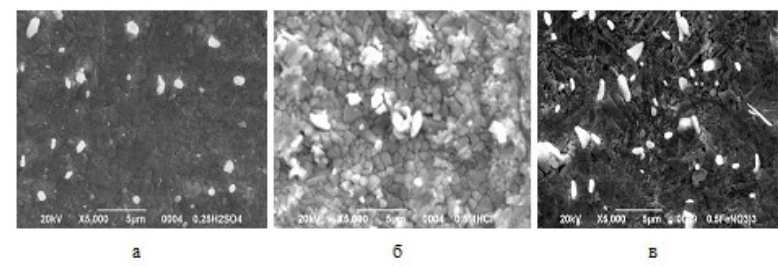

Figure 5. Microphotoes of the surface of bronze $\mathrm{Cu} 98 \mathrm{Be}$ after etching ( $\omega=74 \mathrm{rps})$ in the solutions of composition: a $-\left(0,5 \mathrm{M} \mathrm{FeCl}_{3}-0,5 \mathrm{M} \mathrm{Fe}\left(\mathrm{NO}_{3}\right)_{3}-0,25 \mathrm{M} \mathrm{H}_{2} \mathrm{SO}_{4}\right) ; \sigma-$ $\left(0,5 \mathrm{M} \mathrm{FeCl}_{3}-0,5 \mathrm{M} \mathrm{Fe}\left(\mathrm{NO}_{3}\right)_{3}-0,5 \mathrm{M} \mathrm{HCl}\right) ;$ в - $(0,5 \mathrm{M}$ $\left.\mathrm{FeCl}_{3}-0,5 \mathrm{M} \mathrm{Fe}\left(\mathrm{NO}_{3}\right)_{3}-0,5 \mathrm{M} \mathrm{HNO}_{3}\right)$

\section{Conclusions}

- The process of chemical ionization of Cu98Be alloy in solutions of various composition based on $\mathrm{FeCl}_{3}$ was studied. The etching rate of $\mathrm{Cu} 98 \mathrm{Be}$ and the selectivity of dissolution of the alloy components are determined taking into consideration the processes of complex formation and acidity of the medium in this system. The high etching rate, the uniformity of dissolution process and the beryllium and copper component of the alloy ensure the presence in the etching solution of the ion-oxidizing agent $\mathrm{Fe}^{3+}$ chloride and acidic medium.

- The composition of solutions is selected, which ensures high-speed and uniform etching of the Cu98Be alloy: 1) $0,5 \mathrm{M} \mathrm{FeCl}_{3} ; 2$ ) $0,5 \mathrm{M} \mathrm{FeCl}_{3}+0,5 \mathrm{M} \mathrm{Fe}\left(\mathrm{NO}_{3}\right)_{3}+0,25 \mathrm{M} \mathrm{H}_{2} \mathrm{SO}_{4}$; 3) $0,5 \mathrm{M} \mathrm{FeCl}_{3}+0,5 \mathrm{M} \mathrm{Fe}\left(\mathrm{NO}_{3}\right)_{3}+0,5 \mathrm{M} \mathrm{HCl}$. Taking into account the factors of simplicity and cheapness of the composition at high rates of etching and uniformity of dissolution of both 
components of beryllium bronze $\mathrm{Cu} 98 \mathrm{Be}$, the composition - 0,5 $\mathrm{M} \mathrm{FeCl}_{3}$ is proposed as the optimal one;

- The morphology of the electrode surface from $\mathrm{Cu} 98 \mathrm{Be}$ after etching in solutions, whose composition provides both the highest rate etching and close to 1 values of the selectivity coefficients of dissolution of the alloy components, was studied. It is shown that there is no passivation of the surface after chemical etching in these solutions. The chemical nature of compounds formed as small inclusions on the etched surface of the electrode is established;

-The obtained results are of great importance in practical use because they allow selecting the composition of the etching solution, which in turn helps to optimize the technological etching process and fulfil scientific database about chemical dissolution of the copper alloys.

\section{References}

[1] Medvedev A. Konstruktsii i printsipy izgotovleniya pechatnyh plat. J. Tehnologii v elektronnoy promyshlennosti 2011; 4:12-18.

[2] Budnevich M. Istoriya odnogo proekta. J. Novaya elektronika Rossii, otraslevoy delovoy ezhegodnik 2009:37-39.

[3] Kachagin A, Krivohizhina N, Savitskiy A, Korotkova N. Sozdanie kompleksa izgotovleniya pruzhinnyh detaley. J. Proizvodstvo elektroniki: tehnologii, oborudovanie, materialy 2008;5: 41-46.

[4] Medvedev A. Materialy dlya gibkih pechatnyh plat. J. Tehnologii $\mathrm{V}$ elektronnoy promyshlennosti 2011;3:12-19.
[5] Kondrashin VY, Marshakov IK. Termodinamicheskaya i kineticheskaya obuslovlennost mehanizmov anodnogo rastvoreniya intermetallicheskih faz. J. Vestnik VGU. Seriya himiya, biologiya 2000:5561 .

[6] Starchenko VY, Zozulya VV, Prokopenko VA, Lebovka NI. Perkolyatsionnaya model protsessa formirovaniya nanoporistyh struktur metodom selektivnogo rastvoreniya J. Nanostrukturnoe materialovedenie 2010;1:39-41 .

[7] Moshchenok VI. Inventor; HNADU assignee. Viznachennya tverdosti materialiv vtiskuvannyam sferichnogo indentora. Ukrayina Svidotstvo pro reestratsiyu avtorskogo prava na tvir 48174. 2013. March 4.

Osintsev OE, Fedorov VN, Med i mednye splavy Otechestvennye i zarubezhnye marki. Moscow: Mashinostroenie; 2004, p 336.

[9] Osinskaya Y, Petrov S, Pokoev A. Kompleksnoe eksperimentalnoe issledovanie magnitoplasticheskogo effekta $\mathrm{v}$ medno-berillievom splave. J. Vestnik SamGU - Estestvennonauchnaya seriya 2010;4(78):145-154.

[10] Hobotova EB, Larin VI, Egorova LM, Himicheskoe rastvorenie medi i ee splavov v rastvorah razlichnogo sostava i optimizatsiya tehnologicheskih protsessov travleniya metallov. Kharkov: HNADU, 2008, p 223 .

[11] Sahnenko MD, Ved MV, Shtefan VV, Volobuev MM ,Teoretichni osnovi himiyi ridkisnih i rozsiyanih elementiv. Harkiv: NTU «HPI», 2011, p 424.

[12] Ardashnikova EI. Neorganicheskie ftoridy. J. Sorosovskiy obrazovatelnyy zhurnal 2000;6(8):54-60.

[13] Matyasova VE, Kotsar ML. Poluchenie, svoystva i primenenie soedineniy berilliya vysokoy chistoty. J. Voprsy atomnoy nauki i tehniki 2014; (90):111-119.

[14] Bugaevskiy AA, Muhina TP. Metody rascheta ravnovesnogo sostava $\mathrm{v}$ sistemah s proizvolnym 
kolichestvom reaktsiy. J. Matematika $\mathrm{v}$ himicheskoy termodinamike. Novosibirsk: Nauka 1980; 20-36.

[15] Sillen LG, Martell AE, Stability constants of metal - ion complexes. London: Supplement № 1. Inorganic ligands, 1974, p 481.

[16] Ayerst GG. Ferric chloride as an etching material. J. Trans. Inst. Metal Finish 1966; 44(1):176- 178 .

[17] Burrows WH, Lewis TC, Saire DE, Brooks RE. Kinetics of copper-ferric chloride reaction and the effects of certain inhibitors. J. Industr. Engng. Chem. Process. Design and Developm 1964;3(2):149 159.

[18] Larin VI, Gorobets SD, Hobotova EB, NI Egorkin NI Vliyanie hlorid-iona na rastvorenie medi J. Vestn. Hark. 1989;340:55 - 58.

[19] Larin VI, Hobotova EB, Gorobets SD, Gritsan DN. Vliyanie mezhionnyh vzaimodeystviy na skorost kataliticheskogo protsessa rastvoreniya medi J. Zhurn. prikl. himii 1990;63(3):625 - 630. 